\title{
Alimentation carnée, offrandes funéraires et sacrifices animaux chez les Gaulois
}

Archéozoologie à la fin de l'Âge du Fer en France septentrionale

\section{Patrice Méniel}

\section{OpenEdition}

\section{Journals}

Édition électronique

URL : https://journals.openedition.org/tc/697

DOI : $10.4000 /$ tc. 697

ISSN : $1952-420 X$

\section{Éditeur}

Éditions de l'EHESS

Édition imprimée

Date de publication : 1 novembre 1992

ISSN : 0248-6016

\section{Référence électronique}

Patrice Méniel, « Alimentation carnée, offrandes funéraires et sacrifices animaux chez les Gaulois »,

Techniques \& Culture [En ligne], 17-18| 1992, mis en ligne le 10 janvier 2006, consulté le 29 septembre 2022. URL : http://journals.openedition.org/tc/697 ; DOI : https://doi.org/10.4000/tc.697

Ce document a été généré automatiquement le 29 septembre 2022.

Tous droits réservés 


\section{Alimentation carnée, offrandes funéraires et sacrifices animaux chez les Gaulois}

Archéozoologie à la fin de l'Âge du Fer en France septentrionale

Patrice Méniel 